\title{
EXTRAVASCULAR LUNG WATER ACCUMULATION IN PATIENTS FOLLOWING CORONARY ARTERY SURGERY
}

\author{
Robert J. Byrick, J. Colin Kay and William H. Noble
}

\begin{abstract}
After aORTo-CORONARY BYpass SURGery (A-C Bypass) with haemodilution, the colloid osmotic pressure is reduced. Simultaneously, the pulmonary hydrostatic pressure may be elevated because of left ventricular dysfunction. These factors should promote formation of pulmonary oedema; but attempts to quantitate an increase in pulmonary extravascular water following A-C Bypass surgery have not succeeded. ${ }^{1}$ The tritiated water double indicator dilution technique $\left(\mathrm{TH}_{2} \mathrm{O}\right)$ for measuring lung water, has demonstrated a decrease in post-operative lung water, ${ }^{1-4}$ when applied to patients following cardiopulmonary bypass (C-P Bypass). This finding has been attributed to perfusion dependence of the $\mathrm{TH}_{2} \mathrm{O}$ technique. 2 In animals, the extravascular thermal volume of the lung (ETV $\mathrm{E}_{\mathrm{L}}$ ) measured by a thermal indicator dilution technique appeared to minimize perfusion dependence and to reduce the underestimation of actual lung water ${ }^{5,6} \mathrm{We}$ applied the $\mathrm{ETV}_{\mathrm{I}}$ measurement to patients undergoing A-C Bypass surgery to determine whether it would detect an increase in lung water. We demonstrated an increase in $\mathrm{ETV}_{\mathrm{L}}$ in these patients and related it to changes in intravascular hydrostatic pressure and colloid osmotic pressure.
\end{abstract}

\section{METHODS}

We studied 17 elective patients, chosen at random, who were undergoing saphenous vein A-C Bypass procedures. One patient with pre-operative evidence of pulmonary oedema and another with post-operative cardiac tamponade were excluded.

Patients were premedicated with perphenazine 5 to $10 \mathrm{mg}$, diazepam 5 to 10 $\mathrm{mg}$ and morphine 10 to $15 \mathrm{mg}$. Anaesthesia was induced with Innovar $2 \mathrm{ml}$, d-tubocurare $4 \mathrm{mg}$, a sleep dose of sodium thiopentone and succinylcholine 100 mg. The patients were intubated and ventilated $\left(\mathrm{F}_{\mathrm{O}_{2}}=0.33 ; \mathrm{f} 8-12 / \mathrm{min}\right.$; and VT $10-12 \mathrm{ml} / \mathrm{kg}$ ). Anaesthesia was maintained with nitrous oxide, morphine, diazepam, Innovar and d-tubocurare as necessary. Halothane was used to control hypertension. Base deficits were corrected with $\mathrm{NaHCO}_{3}$ and no steriods were administered. Otherwise anaesthetic management, fluids, vasopressors, diuretic and oxygen administration were left to the discretion of an anaesthetist who was not involved in the study. Extracorporeal circulation was maintained with a nonocclusive roller pump and a bubble oxygenator (Travenol VF-I) with flow rates of $60 \mathrm{ml} / \mathrm{kg} / \mathrm{min}$.

Robert J. Byrick, M.D., Research Fellow; J. Colin Kay, A.I.M.L.T.(Eng.), Research Assistant, and William H. Noble, M.D., F.R.C.P.(C), Associate Professor, Department of Anaesthesia, University of Toronto and St. Michael's Hospital, Toronto, Ontario. 


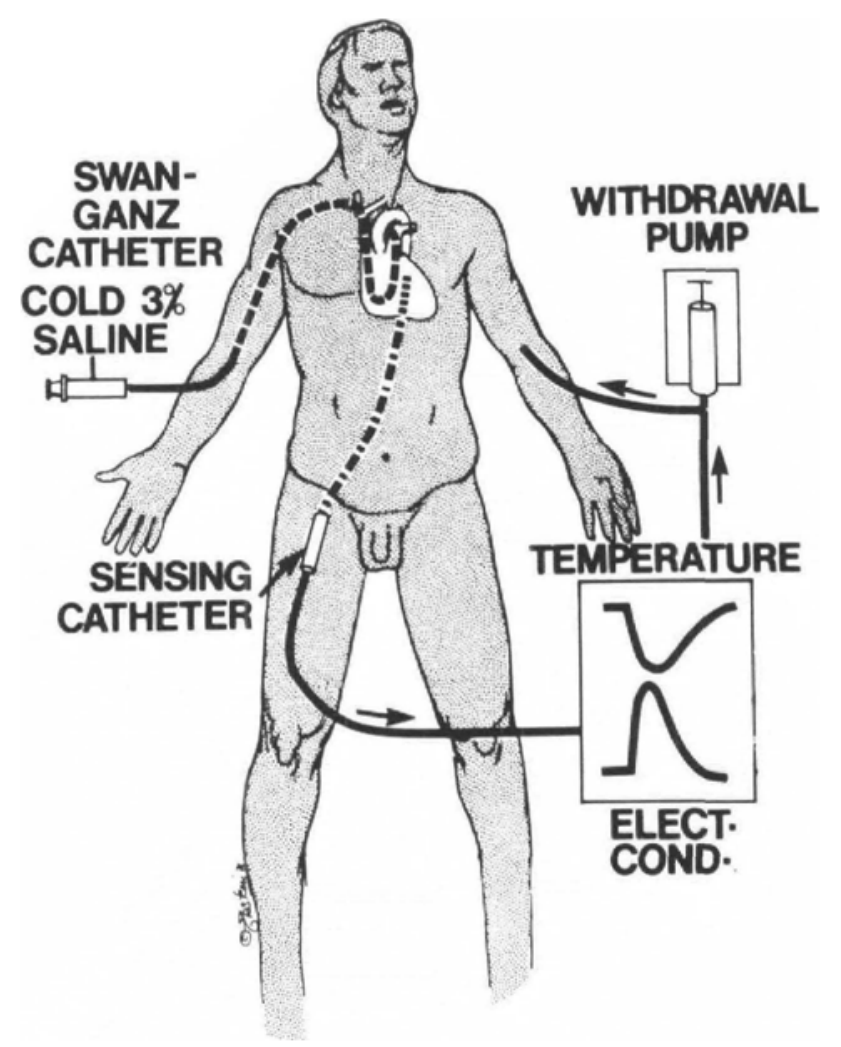

Ficure 1. Catheter positions for $\mathrm{ETV}_{\mathrm{t}}$ technique.

The patients were assigned alternately to one of two groups. In one group (PLASMA) the oxygenator was primed with $400 \mathrm{ml}$ of plasma and $1600 \mathrm{ml}$ of lactated Ringer's solution. In the other group (RINGER'S) the oxygenator was primed with two litres of lactated Ringer's solution alone. Moderate hypothermia $\left(30^{\circ} \mathrm{C}\right)$ was utilized during extracorporeal circulation and heparinization was maintained with an initial dose of 300 units $/ \mathrm{kg}$ followed by half of the preceding dose every 90 minutes while on bypass.

Studies were performed at the following times: CONTROL after anaesthetic induction but prior to operation: POST-OP one to two hours post-operatively; $A M$ 1-the following morning; $P M 1$ - the afternoon of the first post-operative day and $A M$ 2- the morning of the second post-operative day. Since the patients were extubated after the AM 1 measurement, three studies were made while the patient was being ventilated mechanically.

At each study we quantitated extravascular lung water using the technique described by Noble and Severinghaus. ${ }^{5}$ This ETV $_{\mathrm{I}}$. technique requires a SwanGanz catheter with an internal thermistor and an arterial line (Figure 1). Eight $\mathrm{ml}$ of cooled 3 per cent saline were injected into the pulmonary artery (PA). The exact temperature difference between injectate and blood was measured by the thermistor in the Swan-Ganz catheter. The diffusible indicator (calories) and 


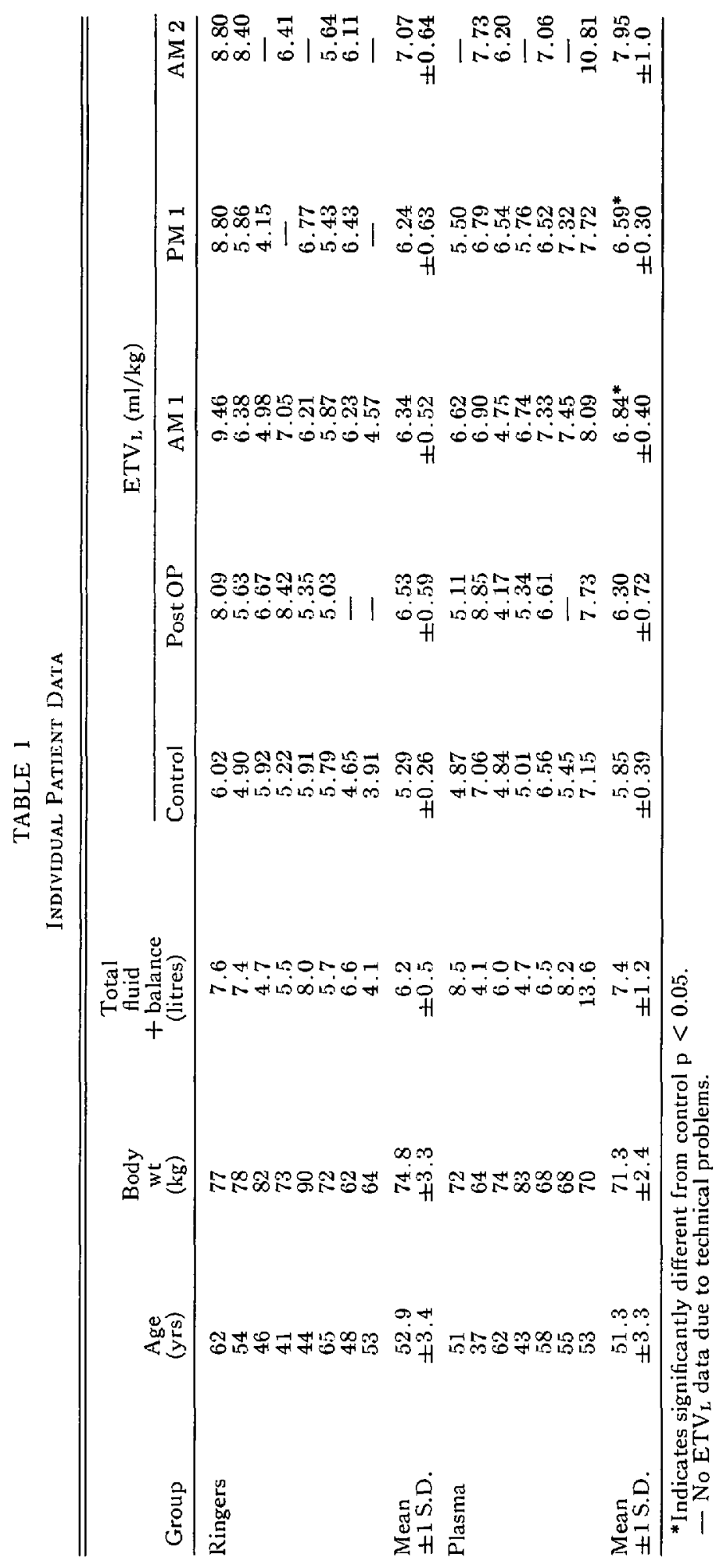


the intravascular indicator (sodium ions) were measured simultaneously by withdrawing blood from the thoracic aorta through the femoral arterial line and through an external sensing catheter. ${ }^{7}$ From the curves obtained we calculated $\mathrm{ETV}_{\mathrm{L}}$, cardiac output $(\dot{\mathrm{Q}})$, and central blood volume (CBV). At each study four or five measurements were made. Shunt fraction ( $\dot{\mathrm{Q}} \mathrm{s} / \dot{\mathrm{Q}} \mathrm{t}),{ }^{8}$ physiologic deadspace ( $V_{D}$ phys)/tidal volume $\left(V_{D} / V_{T}\right),{ }^{9}$ plasma protein concentration (Technicon $\mathrm{N}-14$ Method $),{ }^{10} \overline{\mathrm{PA}}$, wedge $\left(\mathrm{P}_{\text {wedge }}\right)$, central venous and systemic pressures were measured at each study. Pulmonary vascular resistance (P.V.R.) was calculated from the equation:

$$
\text { P.V.R. }=\frac{\overline{P A}-P_{\text {wedge }}}{\bar{Q}}
$$

where P.V.R. is dynes.sec.cm ${ }^{-5}, \overline{P A}$ and $P_{\text {wedge }}$ is in $\mathrm{mm} \mathrm{Hg}$ and $\dot{Q}$ is in $\mathrm{ml} / \mathrm{sec}$.

The colloid osmotic pressure of plasma was calculated from the plasma protein concentration. ${ }^{11} \mathrm{~A}$ direct measure of colloid osmotic pressure was made using an osmometer ${ }^{12}$ and compared to that calculated from plasma protein concentrations in the range encountered in the study. Microvascular hydrostatic pressure $\left(\mathrm{P}_{\mathrm{Xr}}\right)$ was estimated using the formula described by Gaar: $\left(\mathrm{P}_{\mathrm{sY}}=\mathrm{P}_{\text {wedge }}+0.4\right.$ $\left(P_{\Gamma A}-P_{\text {wedge }}\right)^{13}$

Data are presented as means \pm 1 S.E.M. Serial measurements in the same patient are compared to control values using a t-test for independent groups. If $\mathrm{p}<0.05$ the changes are labelled as significant. ${ }^{14}$

\section{Results}

\section{(1) Group Comparability}

The number of successful studies were similar in the two groups as shown in Table I. Mean values for all patients were: total fluid balance in the operating room $6.8 \pm 0.6$ litres, time on pump $122 \pm 12 \mathrm{~min}$; total anaesthetic time $5.6 \pm 0.4$ hours (includes right heart catheterization and measurement time), aortic cross clamp time $10.9 \pm 3.2 \mathrm{~min}$; total blood products in the operating room $1146 \pm 188$ $\mathrm{ml}$ and the number of vessels grafted $2.0 \pm 0.2$. The two groups of patients did not differ significantly with respect to these factors. The two groups were also similar in the amount and type of drugs used pre-operatively (e.g. propranolol) and intra-operatively (e.g. digoxin, furosemide, halothane). There were seven smokers in each group.

\section{(2) Extravascular Lung Water $\left(E T V_{L}\right)$ Measurements}

Mean control ETV $\mathrm{E}_{\mathrm{L}}$ is $5.77 \pm 0.24 \mathrm{ml} / \mathrm{kg}$ total body weight for all patients (Table II). The coefficient of variation for all values of ETV $\mathrm{I}_{\text {. }}$ was 7.07 per cent. There is no difference in ETV $_{\mathrm{L}}$ between the RINGER'S and PLASMA groups of patients at any time during the study period. There is not a significant increase in ETV $_{\mathrm{L}}$ measured immediately following bypass (Figure 2), although the mean value is higher. There is a significant increase in $\mathrm{ETV}_{\mathrm{L}}$ from control to $\mathrm{AM} 1$ measurement in the PLASMA group $(\mathrm{p}<0.025)$ (Table I). When all patients are combined there is a highly significant increase in lung water $(p<0.005)$ on the 


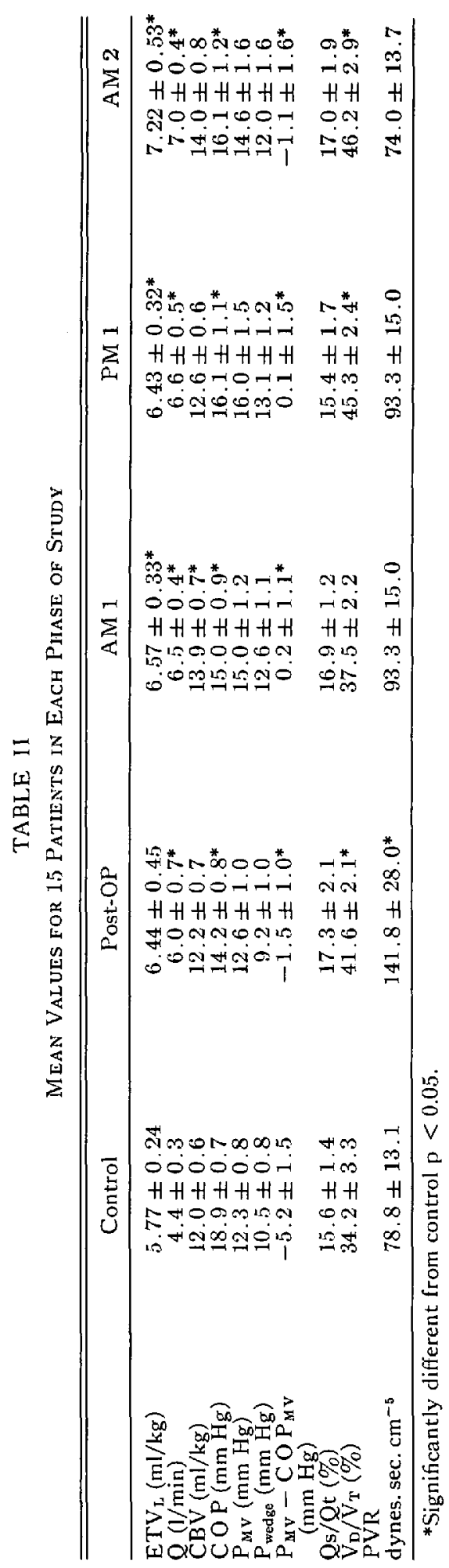




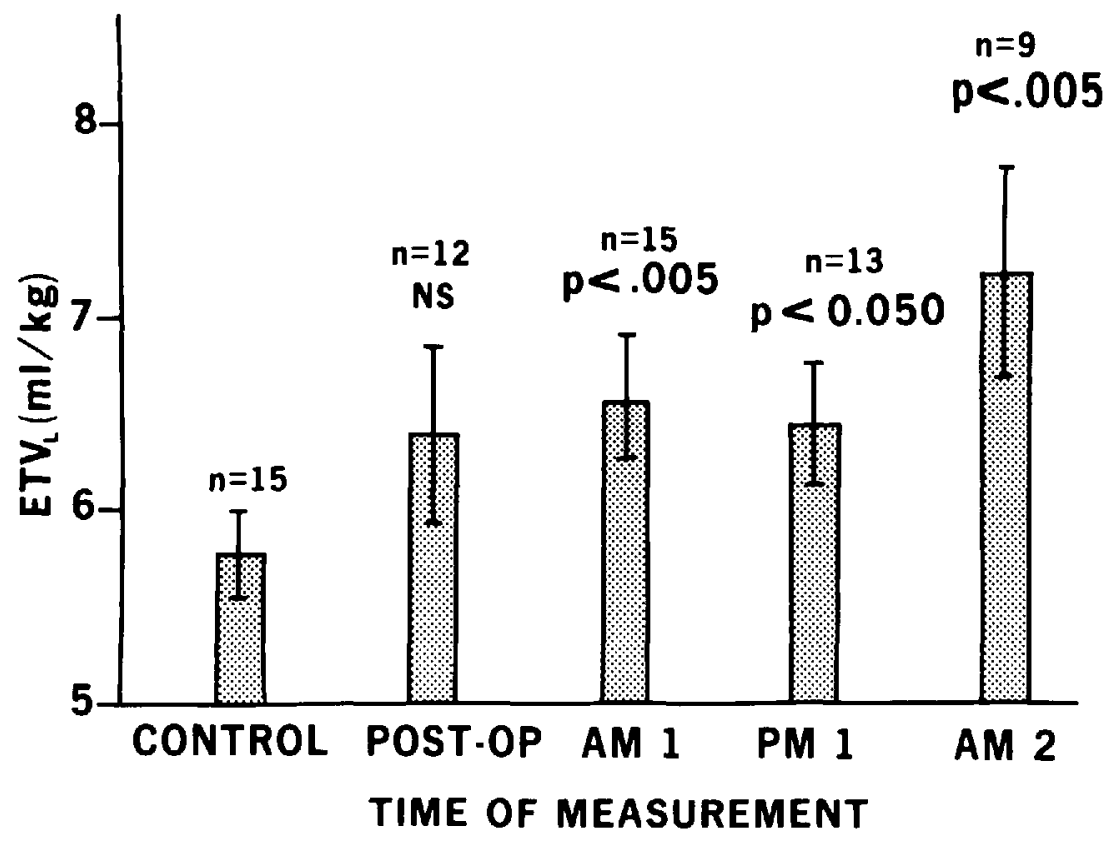

Figure 2. Mean value \pm S.E.M. of $\mathrm{ETV}_{\mathrm{L}}$ for 15 patients at the time measurements were made. p value was obtained with a paired t-test comparing all post-operative values in each patient to his own control value. $\mathrm{p}<0.05$ is considered a significant change.

first and second post-operative days as compared to our control measurement (Figure 2). The increase in $\mathrm{ETV}_{\mathrm{L}}$ did not correlate with the time of C-P Bypass $(r=0.04)$.

\section{(3) Colloid Osmotic Pressure (COP)}

The colloid osmotic pressure calculated from plasma protein concentration related linearly to the direct measurement ${ }^{12}(r=0.98)$. Control colloid osmotic pressure was $18.9 \pm 0.7 \mathrm{~mm} \mathrm{Hg}$ after a night of bed rest and the difference between the RINGER'S and PLASMA groups was not significant (Figure 3 and Table II).

The calculated colloid osmotic pressure of plasma during extracorporeal circulation was significantly higher in the PLASMA group than in the RINGER'S group, but post-operatively this difference disappeared (Figure 3).

Immediately following operation COP rises quickly from a mean of $9.3 \pm 0.2$ $\mathrm{mm} \mathrm{Hg}$ during $\mathrm{C}-\mathrm{P}$ Bypass to $14.2 \pm 0.8 \mathrm{~mm} \mathrm{Hg}$. The post-operative value is still significantly lower $(\mathrm{p}<0.001)$ than the control value. Post-operative COP then increases slowly for the duration of our study but remains significantly lower than the control value (Table II and Figure 3). This confirms the results of other investigators ${ }^{15}$ concerning the rapidity of oncotic normalization following C-P Bypass.

\section{(4) Microvascular Hydrostatic Pressure}

Control $P_{M v}$ was $12.3 \pm 0.8 \mathrm{~mm} \mathrm{Hg}$. It was not significantly elevated after operation although all mean post-operative values are elevated (Table II). There is a 


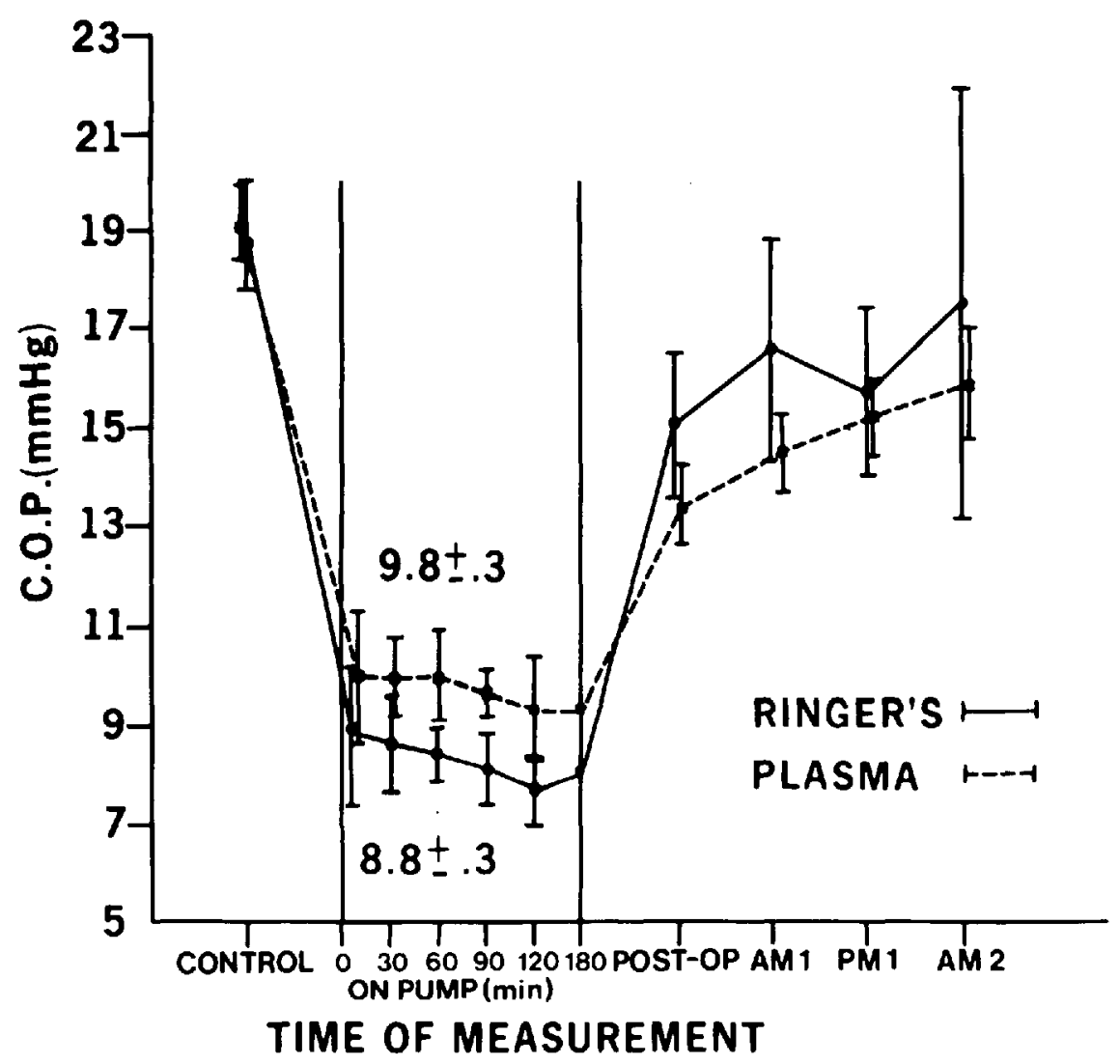

FIGURE 3. Colloid osmotic pressure (COP) changes during cardiopulmonary bypass (on pump) and during the study period.

significant $(r=0.42, p<0.01)$ although not a good relationship between changes in $P_{A N}$ and $E T V_{L}$ from control when all values are plotted. The best significant correlation is between the increase in $\mathrm{ETV}_{\mathrm{L}}$ measured on the first post-operative morning and the increase in calculated $P_{x r}$ above the control $(r=0.78, p<0.01)$. This correlation is also good when $P_{\text {wedpc }}$ is substituted for the calculated $P_{\mathrm{Mr}}$ $(r=0.76, p<0.01)$ Figure 4 .

(5) Intravascular Balance of Starling Forces

$$
\left(\mathrm{P}_{\mathrm{XY}}-\mathrm{COP}_{\mathrm{XY}}\right)
$$

Starling's Law of capillary fluid exchange ${ }^{16}$ states: Fluid transfer $=K\left[\left(\mathrm{P}_{\mathrm{NW}}-\right.\right.$ $\left.\left.\mathrm{P}_{\mathrm{T}}\right)-\left(\mathrm{COP}_{\mathrm{MV}}-\mathrm{COP}_{\mathrm{T}}\right)\right]$ where $\mathrm{K}$ denotes capillary permeability, $\mathrm{P}_{\mathrm{T}}$ is tissue hydrostatic pressure, $\mathrm{COP}_{\mathrm{Ay}}$ is the colloid osmotic pressure in the microvasculature and $\mathrm{COP}_{\mathrm{T}}$ is colloid osmotic pressure in the tissue. Since $\mathrm{K}, \mathrm{P}_{\mathrm{T}}$ or $\mathrm{COP}_{\mathrm{T}}$ cannot be measured clinically $\left[\mathrm{P}_{\mathrm{MY}}-\mathrm{COP}_{\mathrm{MV}}\right]$ is used as an estimate of Starling's relationship, representing the balance of intravascular Starling forces.

The control value for $\left[\mathrm{P}_{M Y}-\mathrm{COP}_{M Y}\right]$ was significantly lower than all postoperative values (Table II). The $\left[\mathrm{P}_{\mathrm{Mr}}-\mathrm{COP}_{\mathrm{MV}}\right]$ rose to its highest value the 


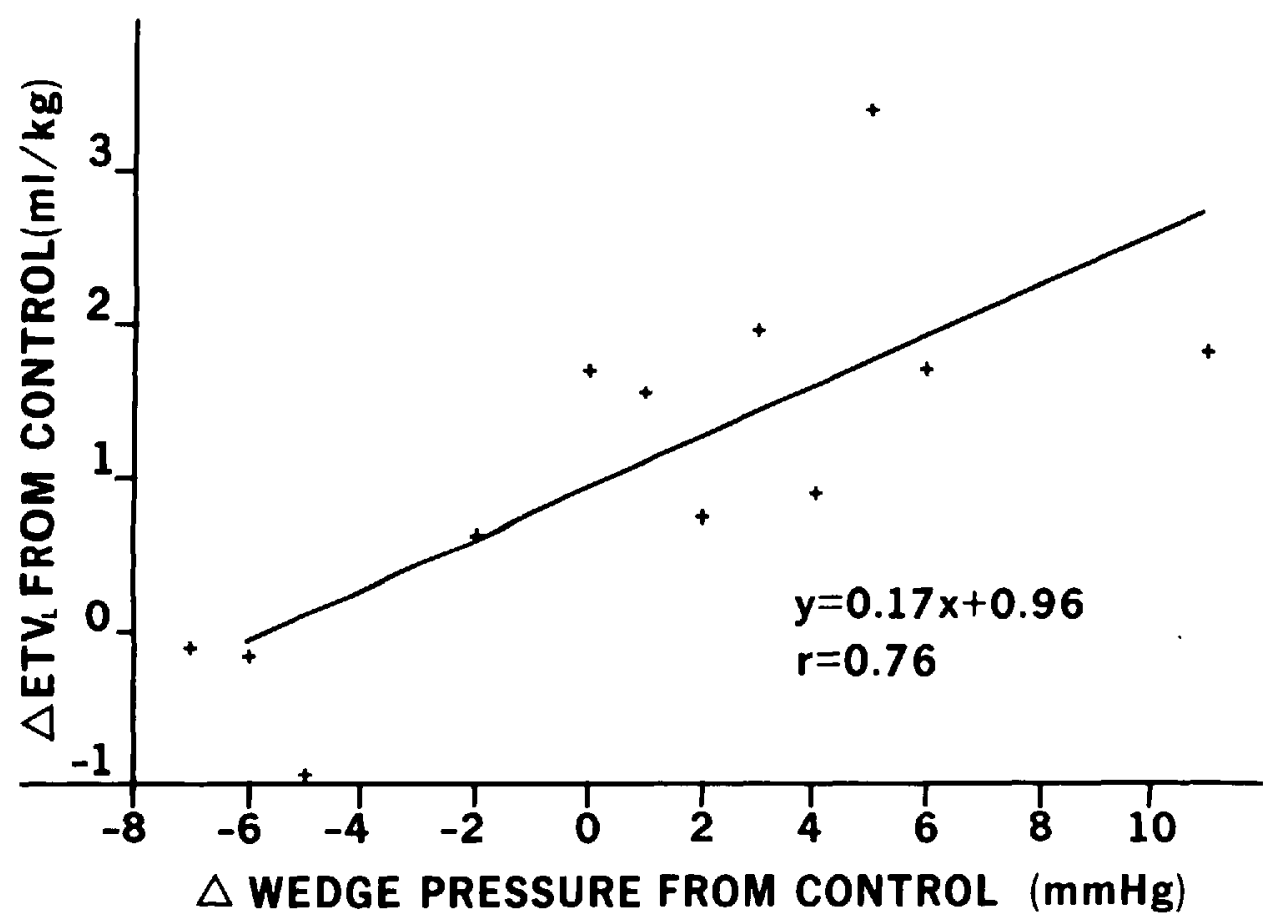

Figure 4. Relationship between the increase in wedge pressure from control to AM 1 measurement and the increase in ETV $_{\mathrm{L}}$ over the same period of time.

first day post-operatively (Table II). This rise is a result of both an increase in $P_{X Y}$ and a reduction in $\mathrm{COP}_{\mathrm{Xr}}$.

The increase of $\mathrm{ETV}_{\mathrm{L}}$ above control at $\mathrm{AM} 1$ correlates well, with the change in the intravascular balance of Starling's Forces $(\mathrm{r}=0.7 \mathrm{~S}, \mathrm{p}<0.01)$, (Figure 5). This balance is derived from the equation $\left[\mathrm{P}_{M V}-\mathrm{COP}_{M V}\right]$.

\section{(6) Shunt Fraction and Physiological Dead Space}

The control $\dot{Q}_{s} / \dot{Q}$ t was $15.6 \pm 1.4$ per cent, range 7.0 to 23.3 per cent, and did not increase significantly at any time (Table II). There was no significant statistical relationship at any time between the change in $\mathrm{ETV}_{\mathrm{T}_{s}}$ and the change in $\dot{\mathrm{Q}} \mathrm{s} / \dot{\mathrm{Q}} \mathrm{t}$. However, one patient who showed the largest single increase in lung water from control to the post-operative measurement $(61.3 \mathrm{per}$ cent) above the control value) also demonstrated the largest increase in $\dot{Q}_{s} / \dot{Q}_{\text {t }}$ (19 per cent above control). This was associated with radiologically visible pulmonary oedema which did not occur in other patients. This was the only patient in whom PA pressure measured during C-P Bypass remained elevated ( $>20 \mathrm{~mm} \mathrm{Hg}$ ), presumably due to inadequate left ventricular venting during operation. ${ }^{17}$

The $V_{D} / V_{T}$ ratio increased significantly from the control value $(34.20 \pm 3.26)$ to the immediate post-operative value $(41.59 \pm 2.09)$ (Table II). Since Vt was held constant from control to AM 1 measurements inclusive this represented an increased $V D$ phys and indicates reduced lung perfusion. The ratio was not signi- 


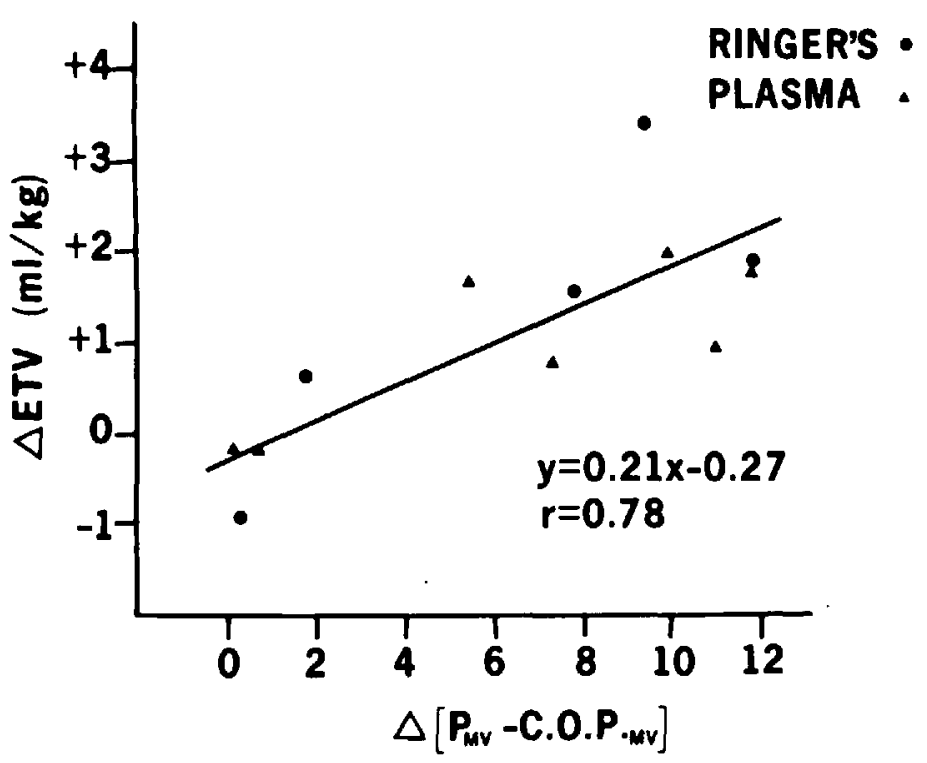

Ficure 5. Relationship between the change in intravascular Starling forces ( $P_{w}-C_{M} P_{w V}$ ) and the change in ETV $\mathrm{V}_{\mathrm{L}}$ from control to AM I measurements.

ficantly different from the control value at AM 1. However, following extubation the mean $V D / V_{T}$ did increase significantly (Table II) at PM 1 and AM 2. This probably represented a fall in $V_{\mathbf{T}}$ after extubation, with an increased respiratory rate.

\section{(7) Pulmonary Vascular Resistance (PVR)}

PVR was significantly elevated immediately after operation when $\dot{Q}$ and Vo phys were also increased (Table II). Since $\dot{Q}$ was elevated the increased PVR means either obstructed or constricted pulmonary vessels. The increased $V_{D}$ phys at the same time supports this conclusion. PVR returned toward control values at AM 1 and remained there throughout the study period. The increased PVR following operation did not correlate with the change in lung water from control to postoperative measurements.

\section{(8) Patient Course}

All patients recovered uneventfully. The only complication of the technique was benign, transient arrhythmia on insertion of the Swan-Ganz catheter. Six balloons ruptured before the second post-operative day, so that no wedge pressure measurements could be made at these times.

\section{Discussion}

\section{(I) Accuracy of Extravascular Lung Water $\left(E_{T} V_{L}\right)$ Measurement}

The ETV $\mathrm{L}_{\mathrm{L}}$ technique used in patients was modified ${ }^{7}$ from the technique used in animals. ${ }^{5}$ The modification was the use of an external sensing catheter placed into 
the standard femoral artery line $50 \mathrm{~cm}, 5.5 \mathrm{Fr}$. polyethylene (Dynetech) instead of an internal sensing catheter. The modified technique gave excellent correlation when compared to the animal technique $(\mathrm{r}=0.96){ }^{7}$ The $\mathrm{ETV}_{\mathrm{I}}$, technique was evaluated by the coefficient of variance ( 7.07 per cent) of 4 or 5 measurements made at each study for all $E T V_{L}$ values, assuming that lung water did not change at each study. The 7.07 per cent variance indicates $\mathrm{ETV}_{\mathrm{L}}$ is a reliably repeatable technique.

The $\mathrm{TH}_{2} \mathrm{O}$ technique for measuring lung water has shown a decrease after $\mathrm{A}-\mathrm{C}$ Bypass. ${ }^{1}$ In contrast our ETV ${ }_{\mathrm{I}}$ data shows an increase in lung water. This difference can be accounted for by the limited repeatability and perfusion dependence of the $\mathrm{TH}_{2} \mathrm{O}$ technique so that only 60 per cent to 70 per cent of lung water is measured. Since the $\mathrm{ETV}_{\mathrm{L}}$ technique can be repeated many times we used an average value for $\mathrm{ETV}_{\mathrm{r}}$, minimizing technical variations which would be present in the one value obtained with the $\mathrm{TH}_{2} \mathrm{O}$ technique. In a direct comparison of $\mathrm{TH}_{2} \mathrm{O}$ and $\mathrm{ETV}_{\mathrm{L}}$ techniques Anderson, et al. ${ }^{6}$ found $\mathrm{TH}_{2} \mathrm{O}$ consistently underestimated lung water while $\mathrm{ETV}_{\mathrm{L}}$ was very accurate. If perfusion to the lung was increased post-operatively $\mathrm{ETV}_{\mathrm{I}}$ might rise but $\mathrm{VD}_{\mathrm{D}} / \mathrm{V}_{\mathrm{T}}$ and PVR should fall. In these patients, our data show that neither mean $V_{D} / V_{T}$ nor PVR fell from control to post-operative values (Table II). Therefore, perfusion dependence did not cause the increases in $\mathrm{ETV}_{\mathrm{I}}$ seen here. Theoretically the nonmolecular thermal indicator would be expected to diffuse better than the molecular $\mathrm{TH}_{2} \mathrm{O}$. This probably accounts for the lack of perfusion dependence with the $\operatorname{ETV}_{L}$ technique. In summary, the $\mathrm{ETV}_{\mathrm{L}}$ technique is superior to the $\mathrm{TH}_{2} \mathrm{O}$ technique because of repeatability, lack of perfusion dependence at the levels of perfusion in these patients, and greater accuracy in measuring all of the lung water both during control periods and early interstitial changes in lung water.6,18 Therefore, ETV $\mathrm{I}_{\text {. }}$ has measured an increase in lung water after A-C Bypass which verifies a widely held clinical impression.

\section{(II) Aetiology of Increased Lung Water}

The time sequence of lung water accumulation does not support the concept that pulmonary oedema develops during C-P Bypass. Although the colloid osmotic pressure on pump was significantly lower in the RINGER'S group of patients, there is not a significant increase in $\mathrm{ETV}_{\mathrm{L}}$ in the immediate post-operative period. Haemodilution with a balanced electrolyte solution leads to little clinical deterioration in pulmonary function. ${ }^{19}$ It is also well tolerated in patients undergoing C-P Bypass. ${ }^{20.21}$ If Starling's relationship applies during C-P Bypass, net fluid transfer will depend on the hydrostatic pressure minus the COP in the microvascular bed at that time. The single case in which the PA pressure during C-P Bypass was elevated above $20 \mathrm{~mm} \mathrm{Hg}$ had the largest increase in ETV $\mathrm{L}(3.2 \mathrm{ml} / \mathrm{kg})$ immediately following cardiopulmonary bypass. This suggests that adequate left ventricular venting may protect the lungs as well as the heart during bypass. ${ }^{22.17}$

Capillary permeability changes cannot be commented upon from our data. However, Brigham, ${ }^{1}$ et al. suggest that there is no gross increase in lung vascular permeability after A-C Bypass.

On the first post-operative day the elevation in $P_{\text {wedge }}$ relates well with $E_{T} V_{L}$ 
changes (Figure $4, \mathrm{r}=0.76$ ). The most obvious cause of the post-operative elevation in $P_{\text {wetre }}$ is left ventricular dysfunction. However, these patients also reabsorb a large fluid load accumulated in the systemic circulation during the perfusion. Diuresis and dehydration may be effective in reducing formation of pulmonary oedema by lowering $P_{\text {wedre, but diuresis has the potential danger of increasing }}$ myocardial oxygen consumption by a hypovolaemia-induced tachycardia. ${ }^{15}$ $\mathrm{P}_{\text {wrdme }}$ might also be reduced with vasodilators (phentolamine or nitroprusside) and positive fluid balance in these patients might be reduced by priming the pump with larger quantities of colloid than were used in our study. In this way postoperative systemic fluid reabsorption might be reduced and the increase in $\mathrm{P}_{\text {widge }}$ prevented.

COP remained significantly reduced from control levels at all times postoperatively. When two units of plasma were used to prime the pump there was not sufficient colloid to increase COP post-operatively. This amount of colloid did not reduce lung water accumulation. However, it is possible that more colloid in the pump prime would maintain the balance of Starling's Forces $\left(\mathrm{P}_{3 Y}-\mathrm{COP}_{\mathrm{MV}}\right)$ so that lung water would not accumulate at higher wedge pressures.

Technical difficulties and balloon breakage leave only six patients by AM 2 for the correlation of $\left[\mathrm{P}_{M V}-\mathrm{COP}_{M V}\right]$ with increased $\mathrm{ETV}_{\mathrm{L}}$. The small number of patients as well as the change to spontaneous ventilation, diuretic therapy and reabsorption of the fluid load make it difficult to interpret the data at AM 2 .

\section{(III) Pulmonary Dysfunction}

The relatively high control values for $\dot{Q}_{s} / \dot{Q}$ t and $V_{D} / V_{T}$ obtained here are attributed to pre-operative ventilation-perfusion mismatch accentuated by the induction of anaesthesia and ventilation..$^{23}$ Norden ${ }^{24}$ reported similar values.

While the mean $\dot{Q} S / \dot{Q} t$ was elevated post-operatively (Table II) a significant increase was not found. This is compatible with the increased $\mathrm{ETV}_{\mathrm{L}}$ found postoperatively since $E T V_{\mathrm{I}}$ increases of less than three $\mathrm{ml} / \mathrm{kg}$ probably represent interstitial oedema which, in dog experiments, has not created shunting. Postoperative shunt fraction is also increased more in patients undergoing open-heart surgery than in closed-heart procedures. ${ }^{-6}$

The significant elevation of $V_{D} / V_{T}$ immediately after operation must represent either new V/Q mismatching or lack of perfusion to portions of the lungs, since $V_{T}$ is constant. Since PVR is elevated at the same time, reduced lung perfusion seems logical. By AM 1 lung perfusion has improved, since both $V_{D} / V_{T}$ and $P V R$ have fallen towards control values. Since PM 1 and AM 2 measurements were made with the patients breathing spontaneously the reduced VT probably contributed to the increased $V_{D} / V_{T}$ at these times.

In summary pulmonary dysfunction as measured in gas exchange was not a major problem in these patients with the exception of one patient whose lung water increase exceeded $3 \mathrm{ml} / \mathrm{kg}^{17}$

\section{(IV) Clinical Significance of Lung Water Changes}

The demonstrated increase in lung water did not impair gas exchange. The relevance of this increase in $\operatorname{ETV}_{\mathbf{L}}$ to the patient's clinical condition must be dis- 
cussed. Early oedema formation is the result of overwhelming of the defense mechanism of the lung (e.g. lymphatic drainage) and subsequent oedema will develop rapidly. It has also been shown by Noble, et al. ${ }^{27}$ that altered compliance resulted from pulmonary congestion and small increases in $\mathrm{ETV}_{\mathrm{T}}$ in dogs. Thus, the increases in $\mathrm{ETV}_{\mathrm{L}}$ may cause or aggravate changes in lung compliance associated with cardiopulmonary bypass. ${ }^{28}$ Prevention of this increase in ETV $\mathrm{L}$, should increase the patient's respiratory reserve and reduce the incidence of post-perfusion pulmonary dysfunction. This should be possible by altering the balance of Starling's Forces $\left(\mathrm{P}_{\mathrm{XY}}-\mathrm{COP}_{\mathrm{XY}}\right)$.

\section{Summary}

We studied patients undergoing A-C Bypass with haemodilution. The bubble oxygenator was primed with either two units of plasma and lactated Ringer's solution (PLASMA) or with lactated Ringer's solution (RINGER'S) alone. We found no difference in pulmonary function or lung water determinations between the Ringer's and the Plasma groups. When all patients were grouped together we found no significant increase in lung water $\left(\mathrm{ETV}_{\mathrm{I}}\right)^{5}$ immediately post-operatively. This suggests lung water did not increase during cardiopulmonary bypass. By the following morning there was a highly significant increase in lung water which was related to changes in the balance between hydrostatic pressure and colloid osmotic pressure and which continued through the second post-operative day. Pulmonary dysfunction, as measured by gas exchange, was not a major problem except in one patient whose lung water increase exceeded $3 \mathrm{ml} \mathrm{H.OO} / \mathrm{kg}$ of total body weight (52 per cent increase) and in whom there was increased shunting. We consider the increase in lung water important, since it may reduce lung compliance and further lung water accumulation. Since the increased lung water was associated with a change in the balance of Starling's forces $\left(\mathrm{P}_{\mathrm{WY}}-\mathrm{COP}_{\mathrm{MV}}\right)$, treatment designed to reduce that balance should reduce lung water accumulation.

\section{RÉSUMÉ}

Chez 17 malades opérés pour pontage aorto-coronarien, nous avons voulu mesurer l'effet de l'hémodilution occasionnée par la circulation extra-corporelle sur le volume d'eau pulmonaire extra-vasculaire $\left(\mathrm{ETV}_{\mathrm{L}}\right)$.

L'oxygénateur à bulles a été amorcé avec un mélange de lactate ringer et de plasma (deux flacons) dans un premier groupe et avec du lactate seul dans un deuxième.

On n'a décelé aucune différence entre les deux groupes au plan de la fonction pulmonaire post-opératoire et des volumes d'eau pulmonaire extra-vasculaire. Lorsqu'on réunit ces malades en un groupe unique, on ne décèle pas d'augmentation de l'eau pulmonaire extra-vasculaire dans les suites opératoires immédiates. Ceci tendrait à démontrer que la circulation extra-corporelle comme telle ne produit pas d'extravasation d'eau au niveau du poumon. Le lendemain matin cependant, l'augmentation de l'eau pulmonaire extra-vasculaire était nettement significative et rattachable à des changements dans l'équilibre des forces hydrostatiques et osmotiquese. Cette augmentation continua à se manifester au deuxième jour post-opératoire. 
La mesure des échanges gazeux n'a pas montré d'insuffisance pulmonaire importante à l'exception d'un seul malade dont l'augmentation de l'eau pulmonaire extra-vasculaire a dépassé les $3 \mathrm{ml} /$ kilo (augmentation de 52 pour cent) et chez qui on a aussi mis en évidence une augmentation de shunt intra-pulmonaire.

Nous considérons que l'augmentation de l'eau pulmonaire extra-vasculaire revèt une importance particulière car elle entraîne une diminution de la compliance pulmonaire et ainsi mène à une plus grande accumulation d'eau extra-vasculaire.

\section{ACKNOWLEDGMENTS}

We thank the anaesthetic staff, cardiologists and cardiovascular surgeons of St. Michael's Hospital for aiding us in the investigation of their patients. The ICU and O.R. staff were most helpful. We appreciate the skillful technical assistance of Mrs. N. Bell, Mr. G. Carmichael and Mr. G. Caskanette from our laboratory. We are grateful to Mrs. G. Buckley for serum protein determinations and Dr. C.E. Webber of McMaster University for the use of his osmometer for C O P measurements. Finally we thank Miss C. Mindorff for help in preparing the manuscript.

This work was supported by MRC grant \#4263 and the Travenol Laboratories Inc.

\section{REFERENCES}

1. Bricham, K.L., Faulkner, S.L., Fisher, D., \& Bender, H. Lung water and urea indicator dilution studies in cardiac surgery patients. Circulation 53: 369 (1976).

2. Pahker, D.J., Karp, R.B., KinkLix, J.W., \& Bedand, P. Lung water and alveolar and capillary volumes after intra-cardiac surgery. Circulation Suppl. 1-139, Vols. 45 and 46, May (1972).

3. O'Conson, N.E., Sheh, J.M., Bantlett, R.H., \& Gazzaninca, A.B. Changes in pulmonary extravascular water volume following mitral valve replacement. Journ. Thor. \& Cardiovasc. Surg. $61: 343$ ( 1971 ).

4. McCredie, M.A. Measurement of pulmonary edema in valvular heart disease. Circulation 36: 381 (1967).

5. Noble, W.H. \& Seveninchaus, J. Thermal and conductivity dilution curves for rapid quantitation of pulmonary edema. J. Appl. Physiol. 32: 770 (1972).

6. Anderson, W.P., Dunegan, L.J., Knight, D.C., Fitzpatrick, G.F., O’Connor, N.E., \& MonGan, A.P. Rapid estimation of pulmonary extravascular water with an instream catheter, J. Appl. Physiol. 39: 843 (1975).

7. KAY, J.C., NobLE, W.H. Lung water estimation using an external sensing catheter. C.A.S.J. in press.

8. Nunn, J.F. Applied Respiratory Physiology, 1st ed, chapter 9: 244, London: Butterworths (1969).

9. Kuwabala, S. \& Duvcalf, D. Effect of anatomic shunt on physiologic deadspace-to-tidal volume ratio: a new equation. Anesthesiology 31:575-577 (1969).

10. Daumas, B.T. \& Biccs, H.G. Determination of serum albumin standard methods of clinical chemistry. Editor-in-Chief, Cooper, G.R. Academic Press, New York, 7: 175 (1972).

11. Landis, E.M. \& Pappinheimer, J.R. Exchange of substances through the capillary walls. Handbook of Physiology Section 2, 2: 974.

12. WebBer, C.E. \& GanNeTt, E.S. The relationship between osmotic pressure and plasma proteins during and after cardiopulmonary bypass. J. Thor. Cardiovasc. Surg. 65: 234 (1973).

13. GaAr, K.A. Jr., Taylon, A.E., Owens, L.J. \& Guyton, A.C. Pulmonary capillary pressure and filtration coefficient in the isolated perfused lung. Am. J. Physiol. 213: 910 (1967).

14. Snedecon, G.W, \& Cochran, W.G. Statistical Methods, 6th ed. Iowa State Press, Iowa (1965). 
15. Beattie, H.W., Evans, G., Garnett, E.S., \& Webber, C.E. Sustained hypovolemia and extracellular fluid volume expansion following cardiopulmonary bypass. Surgery 71: 891 (1972).

16. Starling, E.H. On the absorption of fluids from the connective tissue spaces. J. Physiol. London 19: 312-326 (1896).

17. Byrick, R.J., Finlayson, D.C., \& Nowle, W.H. Pulmonary artery pressure increases during cardiopulmonary bypass: a potential cause of pulmonary edema. Submitted to Anesthesiology.

18. Noble, W.H., Obdrzalek, J., \& Kay, J.C. A new technique for measuring pulmonary edema. J. Appl. Physiol. 34: 508 (1973).

19. Budkley, M.J., Austen, W.G., Goldblatt, A., \& Laver, M.B. Severe hemodilution and autotransfusion for surgery of congenital heart disease. Surgical Forum 22:160 (1971).

20. Cooley, D.A., Crawford, E.S., Howell, J.B., \& Beall, A.C. JR. Open-heart surgery in Jehovah's Witnesses. Amer. J. Cardiol. 13: 779-781 (1964).

21. Laver, M.B. \& Buckley, M.J. Extreme hemodilution in the surgical patient. Hemodilution: theoretical basis and clinical application. Proceedings of an International Symposium. Rottach-Egern, Tegernsee, Germany, Oct. 3-6 (1971). Editor: K. Messmer, H Schmid-Schondein. Basel: S. Karger, pp. 215-228 (1972).

22. Cauert, B.W., Anderson, D.S., Reed, W.A., \& Templeton, A.W. Pulmonary complications following extracorporeal circulation. Southern Med. J. 64: 679 (1971).

23. Rehder, K., Sesscer, A.D., \& Marsh, H.M. General anaesthesia and the ling. American Review of Respiratory Disease. 112: 541-563 (1975).

24. Nordes, I., Norlander, O., \& Rodriquez, R. Ventilatory and circulatory effects of anaes. thesia and cardiopulmonary bypass. Acta Anaesth. Scandinav. 14: 297 (1970).

25. Noble, W.H., Kovacs, K., \& KaY, J.C. Fine structural changes in hemodynamic pulmonary oedema. C.A.S.J. 21: 275-284 (1974).

26. Nahas, R.A., Melrose, D.G., Sykes, M.K., \& Robinson, B. Post-perfusion lung syndrome: Role of circulatory exclusion. Lancet, August 7 ( 1965).

27. Noble, W.H., Kax, J.C., \& Obdrzalek, J. Lung mechanics in hypervolemic pulmonary edema. J. Appl. Physiol. 38: 681 (1975).

28. Edmunds, L.H. \& Austen, G.W. Effect of cardiopulmonary bypass on pulmonary volumepressure relationships and vascular resistance. J. Appl. Physiol. 21: 209 (1966). 